\title{
Coronary spastic angina after the administration of intravenous immunoglobulin in myasthenia gravis: a case report
}

\author{
Masaru Yanagihashi ${ }^{1 *}$, Ryuichi Okamoto ${ }^{1}$, Harumi Morioka ${ }^{1}$, Masahiro Sawada', Shingo Matsumoto², \\ Takanori Ikeda ${ }^{2}$ and Osamu Kano ${ }^{1}$
}

\begin{abstract}
Background: Myasthenia gravis (MG) is an autoimmune disease caused by antibodies that block or destroy nicotinic acetylcholine receptors at the neuromuscular junction. Most of MG patients need immunosuppression agents in addition to treatments that alleviate the symptoms. Intravenous immunoglobulin (IVlg) and plasma exchange are specific treatments given to patients with severe MG and myasthenia gravis crisis. IVlg therapy can cause an increase in serum viscosity; therefore, the risk for thromboembolic events, such as stroke, myocardial infarction, and pulmonary embolism, are reported after IVlg therapy.

Case presentation: An MG patient was treated with pyridostigmine bromide and prednisolone. The patient's symptoms worsened 26 days after the commencement of treatment and was presented with head drop and dyspnea. The patient was diagnosed with MG crisis and IVIg was initiated. However, the patient reported chest pain and dyspnea 3 days after IVIg had started. An electrocardiogram (ECG) revealed ST elevations in leads II, III, and aVF. A cardiac catheterization was performed and stenosis, obstruction, and sclerosis were ruled out. Glyceryl trinitrate relieved the patient's symptoms, suggesting coronary spastic angina (CSA).
\end{abstract}

Conclusions: We report the first case of CSA after IVIg. Practitioners should be aware of the potential risks of CSA when administering IVIg for MG patients, in particular in old patients with vascular risk factors.

Keywords: Coronary spastic angina (CSA), Intravenous immunoglobulin (IVIG), Myasthenia gravis (MG)

\section{Background}

Myasthenia gravis (MG) is an autoimmune disorder of the neuromuscular junction (NMJ), manifesting as skeletal muscle fatigable weakness. In most cases of MG, the number of available acetylcholine receptors is decreased due to the autoimmune attack. However, the musclespecific kinase, lipoprotein receptor-related protein 4 ,

\footnotetext{
* Correspondence: masaru.yanagihashi@med.toho-u.ac.jp

'Division of Neurology, Toho University Omori Faculty of Medicine, 6-11-1, Omorinishi, Ota-ku, Tokyo 143-8541, Japan

Full list of author information is available at the end of the article
}

agrin, titin, and ryanodine receptors are targeted in some cases of MG [1, 2].

Acetylcholinesterase inhibitors and immunosuppressive agents such as prednisolone and azathioprine are effective in treating MG. However, patients with MG crisis that require intubation or noninvasive ventilation should receive immunosuppressive agents and intensive care [2]. In MG exacerbation and crisis, intravenous immunoglobulin (IVIg) and plasma exchange are recognized as effective therapies, providing benefits within 2 weeks of treatment commencement $[3,4]$. IVIg is often regarded as convenient and safe for

(c) The Author(s). 2020 Open Access This article is licensed under a Creative Commons Attribution 4.0 International License, which permits use, sharing, adaptation, distribution and reproduction in any medium or format, as long as you give appropriate credit to the original author(s) and the source, provide a link to the Creative Commons licence, and indicate if changes were made. The images or other third party material in this article are included in the article's Creative Commons licence, unless indicated otherwise in a credit line to the material. If material is not included in the article's Creative Commons licence and your intended use is not permitted by statutory regulation or exceeds the permitted use, you will need to obtain permission directly from the copyright holder. To view a copy of this licence, visit http://creativecommons.org/licenses/by/4.0/ The Creative Commons Public Domain Dedication waiver (http://creativecommons.org/publicdomain/zero/1.0/) applies to the data made available in this article, unless otherwise stated in a credit line to the data. 
most MG crisis cases, but severe side effects including anaphylactic reactions, aseptic meningitis, acute renal failure, and thromboembolic events such as stroke, myocardial infarction, deep vein thrombosis, and pulmonary embolism have been reported [5].

We present the first reported case of coronary spastic angina (CSA) following IVIg administration to an MG crisis patient who suffered from head drop and dyspnea.

\section{Case presentation}

An 87-year-old woman with osteoporosis and a lumbar compression fracture was transferred to our hospital for suspected MG due to a gradual increase of limb weakness and an anti-acetylcholine receptor (AChR) antibody level. The patient underwent surgery for a pressure ulcer on her lumbar spine 8 months prior. Her medical history was significant for falx meningioma, right kidney tumor, colorectal polyp removal, bile cyst enucleation, and diabetes mellitus.

The patient had noticed grip weakness for more than a year, and bilateral ptosis and diplopia for the past 3 months. Swallowing was normal, but she had difficulty chewing. The patient was a non-smoker, but her pulmonary capacity was decreased due to a restrictive ventilatory disorder. The patient's AChR antibody increased to 75 $\mathrm{nmol} / \mathrm{L}$. Repetitive nerve stimulation electromyogram was performed on right accessory nerve, facial nerve and ulnar nerve. Waning in the orbicularis muscle ( $24 \%$ decrement) and abductor pollicis (19\% decrement) was observed on 3 $\mathrm{Hz}$ stimulation. Computed tomography of the chest revealed no thymoma. The patient was diagnosed with MG, and her quantitative myasthenia gravis (QMG) score was 18 points. She was prescribed with an acetylcholinesterase inhibitor, pyridostigmine bromide ( $120 \mathrm{mg}$ per day), and increments of prednisolone, starting at $5 \mathrm{mg}$ every other day and titrated up to $10 \mathrm{mg}$ once a day for 2 days. However, after 26 days of therapy, the patient's symptoms worsened, with head drop and gradually fluctuating dyspnea; thus, the patient was diagnosed with MG crisis and we initiated IVIg ( $400 \mathrm{mg} / \mathrm{kg}$ per day), continuous infused at $500 \mathrm{~mL}$ per day.

Three days after starting IVIg, the patient reported sudden chest pain and dyspnea in the evening. She had taken her last dose of pyridostigmine bromide after lunch that day. An electrocardiogram (ECG) revealed ST elevations in leads II, III, and aVF (Fig. 1). A cardiac catheterization was performed and stenosis, obstruction, and sclerosis were ruled out. Glyceryl trinitrate $(48 \mathrm{mg}$ per day), improved the patient's symptoms, which suggested that the coronary arteries were in spasm (Figs. 1, and 2). The patient was started on nicorandil and has had no recurrence of chest pain for 1 year.

\section{Discussion and conclusion}

MG treatment includes oral acetylcholinesterase inhibitors such as pyridostigmine bromide and immunosuppressive

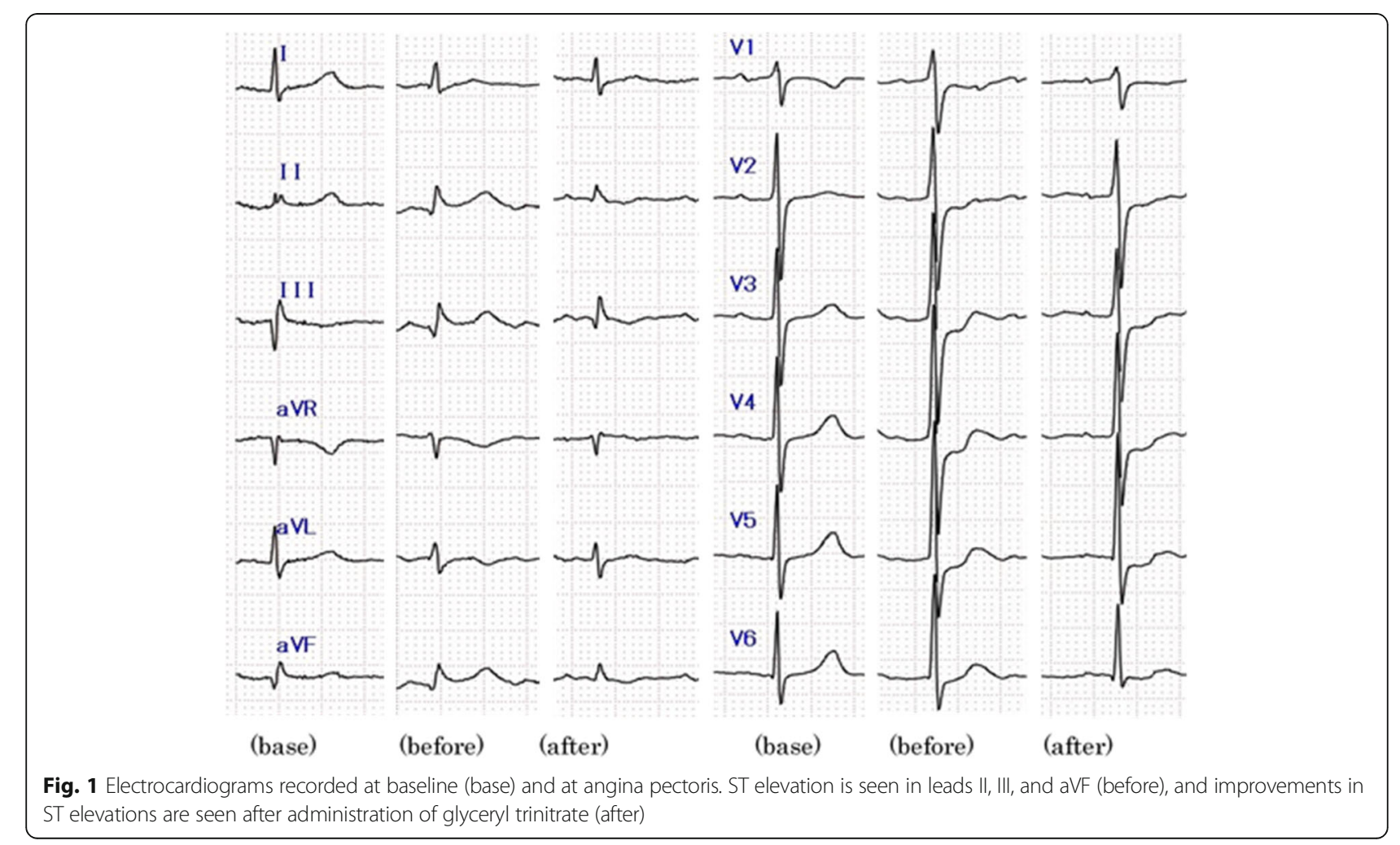




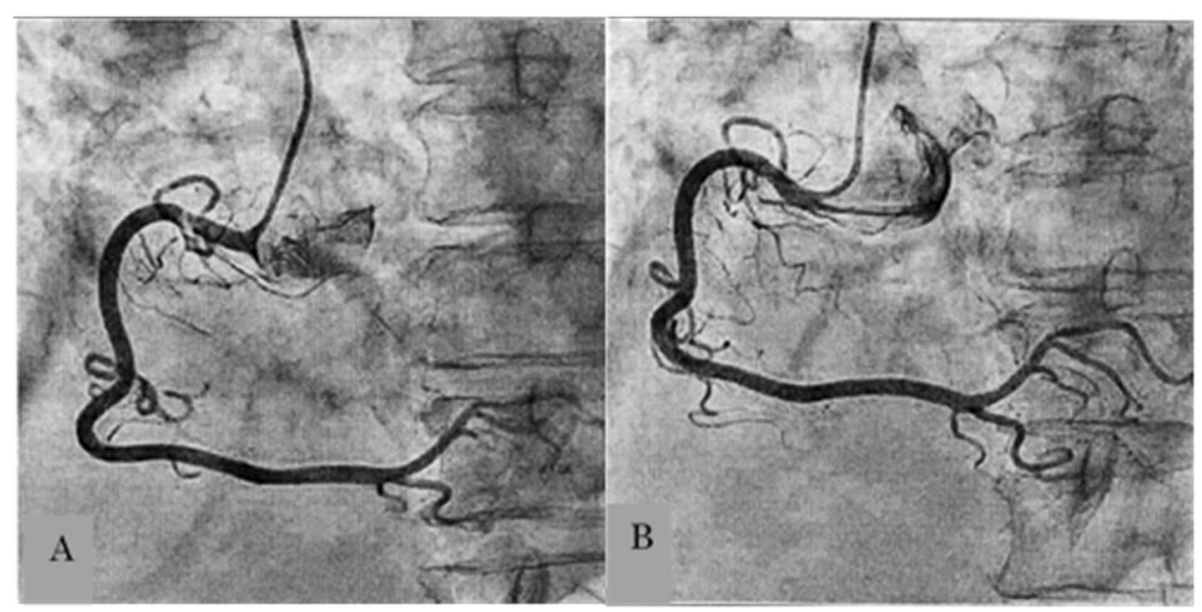

Fig. 2 Cardiac catheterization shows the right coronary artery in spasm before treatment (a) and relieved after administering glyceryl trinitrate (b)

drugs. Moreover, patients with MG exacerbation or crisis are treated with intubation or noninvasive ventilation, IVIg, and plasma exchange. We decided to administer IVIg in this case when the patient exhibited head drop and dyspnea as signs of MG crisis. Previously, stroke, myocardial infarction, and other thrombotic complications have been reported as rare but severe side effects of IVIg, due to the associated increase in blood viscosity [5, 6]. In this case, we considered the patient's chest pain and dyspnea to be acute ischemic heart disease or pulmonary embolism in response to IVIg. We could not perform enhanced computed tomography of the chest and abdomen to exclude pulmonary embolism, pneumothorax and aortic dissection. However, the improvement seen with the injection of glyceryl trinitrate would suggest coronary artery spasm rather than stenosis or obstruction.

Previous reports have suggested that there is a deficiency of nitric oxide (NO) activity in the endothelial cells of the coronary arteries with CSA [7]. Moreover, the spastic arteries are sensitive to nitroglycerin, a vasodilator, and to the effect of acetylcholine, a parasympathetic neurotransmitter, which can induce vasospasm by constricting the vascular smooth muscle when the endothelium is damaged [7-11]. Other reports showed that atherosclerotic lesions detected by intravascular ultrasound may be sites of focal vasospasm, even in the absence of significant angiographically confirmed coronary disease [12]. The patient had diabetes mellitus, so there may have been undetected atherosclerotic lesions at the site of the spasm.

A case of CSA induced by acetylcholinesterase inhibitor (ambenonium chloride) had been reported in an MG patient 3 weeks after dosing [13]. The patient in this report had taken pyridostigmine bromide, an acetylcholinesterase inhibitor, for 25 days, with her last dose several hours before CSA symptoms were noted. IVIg therapy in severe MG and MG crisis shows rapid effect, so there is no speculation, we hypothesized that the CSA might be induced by IVIg rather than the acetylcholinesterase inhibitor.

As shown in previous studies, IVIg has multiple modes of action, which include activation of bacterial phagocytosis, Fc receptors blockade, complement downregulation, suppression of cytokine activity modulation of dendritic cells, and $\mathrm{T}$ and $\mathrm{B}$ cell activation and differentiation [14]. In addition, IVIg may induce the production of vasoconstrictive cytokines, arterial vasospasm, and disrupt atherosclerotic plaques leading to thrombotic events $[15,16]$. IVIg therapy causes an increase in serum viscosity; therefore, the risk for thromboembolic events such as myocardial infarction, pulmonary embolism, and stroke, especially in patients with risk factors for cerebral vascular disease as in our case, must be considered. Further study is required to confirm the relationship between IVIg and CSA. Practitioners should be aware of the potential risk of CSA, and we recommend caution when administering IVIg to treat MG patients, particularly in elderly patients with vascular risk factors and several comorbidities.

\section{Acknowledgements}

We would like to thank the cardiologists who performed cardiac catheterization and treated. Moreover, we would like to thank Editage (www.editage.com) for English language editing.

\section{Authors' contributions}

MY wrote the initial draft of the manuscript. RO, HM, MS, SM and TI were involved in treatment planning, medical data collection. OK contributed to interpretation of the findings and critical revision of the manuscript. All authors read and approved the final manuscript.

Funding

Not applicable. 


\section{Availability of data and materials}

All data resides within the author's premises and is available to the author upon reasonable request.

\section{Ethics approval and consent to participate}

Not applicable.

\section{Consent for publication}

Written informed consent was obtained from the patient's son for the publication of this case report, data and images. A copy of the written consent is available for review by the editor of this journal.

\section{Competing interests}

The authors declare that there are no competing interests.

\section{Author details}

'Division of Neurology, Toho University Omori Faculty of Medicine, 6-11-1, Omorinishi, Ota-ku, Tokyo 143-8541, Japan. ${ }^{2}$ Division of Cardiovascular Medicine, Toho University Omori Faculty of Medicine, Tokyo, Japan.

Received: 26 June 2020 Accepted: 23 August 2020

Published online: 28 August 2020

\section{References}

1. Meriggioli MN, Sanders DB. Autoimmune myasthenia gravis: emerging clinical and biological heterogeneity. Lancet Neurol. 2009:8:475-90.

2. Gilhus NE. Myasthenia gravis. N Engl J Med. 2016;375:2570-81.

3. Gajdos P, Chevret S, Clair B. Clinical trial of plasma exchange and high-dose intravenous immunoglobulin in myasthenia gravis. Myasthenia gravis clinical study group. Ann Neurol. 1997:41:789-96.

4. Barth D, Nabavi Nouri M, Ng E, Nwe P, Bril V. Comparison of IVIg and PLEX in patients with myasthenia gravis. Neurology. 2011;76:2017-23.

5. Hamrock DJ. Adverse events associated with intravenous immunoglobulin therapy. Int Immunopharmacol. 2006:6:535-42.

6. Bilal J, Riaz IB, Hill JL, Zangeneh T. Intravenous immunoglobulin-induced pulmonary embolism: it is time to act! Am J Ther. 2016;23:e1074-7.

7. Kugiyama K, Yasue H, Okumura K, Ogawa H, Fujimoto K, Nakao K, et al. Nitric oxide activity is deficient in spasm arteries of patients with coronary spastic angina. Circulation. 1996;94:266-71.

8. Yasue $H$, Horio $Y$, Nakamura N, Fujii H, Imoto N, Sonoda R, et al. Induction of coronary artery spasm by acetylcholine in patients with variant angina: possible role of the parasympathetic nervous system in the pathogenesis of coronary artery spasm. Circulation. 1986;74:955-63.

9. Okumura K, Yasue H, Horio Y, Takaoka K, Matsuyama K, Kugiyama K, et al. Multivessel coronary spasm in patients with variant angina: a study with intracoronary injection of acetylcholine. Circulation. 1988;77:535-42.

10. Sekiya M, Okayama H, Suzuki M, Kobayashi T, Matsuoka H, Sumimoto T, et al. Acetylcholine-induced myocardial ischemia without epicardial coronary artery spasm: a possible vasospasm of small coronary arteries--a case report. Angiology. 1993:44:811-5.

11. Furchgott RF, Zawadzki JV. The obligatory role of endothelial cells in the relaxation of arterial smooth muscle by acetylcholine. Nature. 1980;288:373-6.

12. Yamagishi M, Miyatake K, Tamai J, Nakatani S, Koyama J, Nissen SE. Intravascular ultrasound detection of atherosclerosis at the site of focal vasospasm in angiographically normal or minimally narrowed coronary segments. J Am Coll Cardiol. 1994:23:352-7.

13. Suzuki M, Yoshii T, Ohtsuka T, Sasaki O, Hara Y, Okura T, et al. Coronary spastic angina induced by anticholinesterase medication for myasthenia gravis-a case report. Angiology. 2000;51:1031-4.

14. Negi VS, Elluru S, Siberil S, Graff-Dubois S, Mouthon L, Kazatchkine MD, et al. Intravenous immunoglobulin: an update on the clinical use and mechanisms of action. J Clin Immunol. 2007;27:233-45.

15. Sherer $Y$, Levy $Y$, Langevitz P, Rauova L, Fabrizzi F, Shoenfeld Y. Adverse effects of intravenous immunoglobulin therapy in 56 patients with autoimmune diseases. Pharmacology. 2001;62:133-7.

16. Paran D, Herishanu Y, Elkayam O, Shopin L, Ben-Ami R. Venous and arteria thrombosis following administration of intravenous immunoglobulins. Blood Coagul Fibrinolysis. 2005;16:313-8.

\section{Publisher's Note}

Springer Nature remains neutral with regard to jurisdictional claims in published maps and institutional affiliations.
Ready to submit your research? Choose BMC and benefit from:

- fast, convenient online submission

- thorough peer review by experienced researchers in your field

- rapid publication on acceptance

- support for research data, including large and complex data types

- gold Open Access which fosters wider collaboration and increased citations

- maximum visibility for your research: over $100 \mathrm{M}$ website views per year

At BMC, research is always in progress.

Learn more biomedcentral.com/submissions 